\title{
Evaluating the Intervention of an Ethics' Class in Students' Ethical Decision-Making: A Summative Review
}

\author{
Marquita Walker ${ }^{1}$ \\ ${ }^{1}$ Labor Studies Program, School of Social Work, Indiana University-Purdue University Indianapolis, \\ Indianapolis, USA \\ Correspondence: Marquita Walker, Labor Studies Program, School of Social Work, Indiana University-Purdue \\ University, Indianapolis, Indianapolis, IN 46202, USA. Tel: 1-317-278-2066. E-mail: marqwalk@iupui.edu
}

Received: August 1, 2012 Accepted: August 6, 2012 Online Published: November 12, 2012

doi:10.5539/ies.v6n1p10 URL: http://dx.doi.org/10.5539/ies.v6n1p10

\begin{abstract}
This summative evaluation is the result of two years' of data reflecting the impact of an ethics class in terms of students' ethical decision-making. The research compares aggregate responses from scenario-based pre- and post-survey open-ended survey questions designed to measure changes in ethical decision-making by comparing students' cognitive and affective perceptions about ethical workplace behavior. Grounded in constructivist theory, which explains how individuals "know" and "come to know something (Reeves, 2003), this intervention of an ethics class encourages students to make better and more informed ethical decisions in the workplace based on their understanding of their value and belief system. The findings suggest the intervention of an ethics class informed students' cognitive and affective perceptions based on individual value and belief systems, strengthened student's ability to remain open-minded and reconsider previous beliefs and actions from a 360 degree perspective, and increased student's ability to apply new information to ethical dilemmas in the workplace.
\end{abstract}

Keywords: ethical decision-making, constructionist theory, cognitive and affective perceptions

\section{Introduction}

An increased awareness in ethic's instruction and the concept of ethical decision making in organizations is currently prevalent in light of fraudulent, deceitful, and deceptive workplace practices which quickly impact many in a workplace environment. Though devious workplace practices have always existed the increasing disregard for ethical behavior in the workplace has reached unprecedented heights as evidenced by multiple scandals in firms across the country (Anderson, 2008). Workers, defined as wage earners in management and labor, are faced with ethical dilemmas requiring choices which impact themselves and other stakeholders. The question of whether ethics, also known as moral philosophy, can or cannot be taught looms large. The inclusion of ethics courses in higher education curriculum may help resolve this problem (Lind, 2010). Some believe ethics should be incorporated in most formal education settings to expose all students to a "common method of resolving ethical dilemmas" (Carlson \& Burke, 1998, p. 1180). Some believe ethical training should at least raise awareness of ethical dilemmas (Briggs, 1993) or develop cognitive skills in solving ethical dilemmas (Kavthatzopoulos, 1991). Others suggest formal ethics training has little or no effect at all (Abell, 1990; Weber, 1990).

Others, particularly in the management arena, believe ethics' instruction should not be included in the curriculum and add those who teach business classes should remain engaged in activities to increase profits and nothing else (Drucker, 1981; Friedman, 1970). Still others suggest an individual's value system does not necessarily translate into making good ethical decisions so instruction in ethic's training is essential (Goodpaster, 1983; Hoffman, 1982). The general consensus is currently that ethics classes are needed to raise awareness of ethical issues and to move ethical thinking and behavior in a more ethical direction (Boyd, 1981; Cohen, 1989; McDonald \& Donleavy, 1995; Stead \& Miller, 1988).

Since the intent of ethic's instruction is to encourage individuals to make more positive ethical decisions by changing cognitive thinking patterns, it makes sense to design studies which measure the success or failure of ethic's instruction. Part of the problem in designing studies which measure changes in ethical decision-making is the lack of consistency in the definition of what constitutes ethical behavior in human resources and industrial 
relations (HRIR) or the employment relationship between labor and management (Budd, 2005; Provis, 2006). In professional fields in which ethical codes exist, ethical decisions can be judged against some standard of ethical behavior established, published, and collectively and individually agreed upon by the profession. Absent a specific ethical code, workers must make ethical decisions based on their own perceptions of right and wrong. Pimentel (2008) attributes these inconsistencies to various theoretical models and empirical findings as the result of "different foci and methodological orientations" (p. 360) and suggests the present models are insufficient because they fail to consider the impact of individual characteristics such as '"closeness,' 'relationships,' and 'moral virtue"' on ethical dilemmas. Provis (2006) points out, "the ideas of 'labor' and 'management' are not perfectly straightforward ideas" (p. 64), so the division between the free market or efficiency ethos promoted by management and the equity-based or human value ethos promoted by labor has created a "moral vacuum" (Budd, 2005 , p. 2) in which little attention has been paid to the scholarship of HRIR.

Ethical Dilemmas in the Workplace, a sixteen-week semester class delivered online, is designed to explore the fundamental basis for ethical decision-making in unionized and non-unionized workplaces, to improve critical thinking skills about specific moral issues such as human dignity and respect, and to determine what actions should be taken when faced with an ethical dilemma. The course description is as follows:

This course explores the fundamental basis for ethical decision making in a workplace, both unionized and nonunionized. We will discuss specific considerations for making moral judgments within the work environment and explore the basis upon which those decisions are made. We seek to improve our thinking about specific moral issues such as human dignity and respect. This helps us determine what actions we should or should not take in our daily lives which, in turn, fashions our answers to questions affecting how society should or should not be structured. Each field of work or social activity has a code of ethical conduct which is either understood or formally written. Each individual within the profession should understand the value of this code and understand how decisions made in the workplace have an effect on the work environment and, by extension, other workers (Walker, 2011).

The first two weeks of instruction are spent exploring the philosophical underpinnings of foundational belief systems rooted in two divergent philosophical paths: Hellenistic Christianity (religion) and various forms of Aristotelian philosophy (science) which can be traced through the various writings of philosophers (Kant, [1781] 1963; Locke, 1690; Mill, [1863] 2003). Students are encouraged to think about their own value and belief system in light of these foundational pieces. Attention is also given to Rest's (1984) four components of consistent ethical behavior: ethical or moral sensitivity, judgment, intent, and actions. The next few weeks involve learning various techniques for making personal ethical decisions based on Goree's ETHICS model (Goree, 2007), Gilligan's Caring Model (Gilligan, 1982, 1993), and Kohlberg's Justice Model (Lawrence Kohlberg, 1981). An introduction to Derrida's theory of deconstruction explores how texts can be illuminated by "reading between the gaps" and helps students to critically analyze a text (Derrida, 1978). The next four lectures explore Kantian ethical thought as well as some non-Western ethical frameworks and how those theories might fit into the current U.S. system of industrial relations (Budd, 2005). The last half of the semester moves from a theoretical approach to ethical decision-making to a practical approach to ethical decision-making. During these seven lectures, students are exposed to real-life situations in a globalized and corporatist environment in which workers, whether union or non-union, labor or management, daily faced with ethical dilemmas, must apply previously learned theories in order to make ethical choices. A required group project utilizing all the skills students have acquired during the course culminates in students, divided into teams of five, creating an ethical code for a fictitious organization which displays unethical behavior. Students are assigned one of various organizations represented: union, non-union, for-profit, not-for-profit, and faith-based. The ethical code developed must reflect ethical standards of all stakeholders in the organization: owners, managers, employees, suppliers, and consumers.

Each semester the class has between twenty-five and thirty-five students. Prior to the beginning of the semester, each student is sent a request to participate in an online survey, which asks for demographic information as well as narrative responses to nine scenario-based questions involving ethical workplace decisions. At the end of the semester, the students have the opportunity to participate in the same survey. Students self-select into the study and remain anonymous. Students' narrative responses, coded for emerging patterns which are then categorized into themes, form the basis for a comparative analysis concerning changes in cognitive and affective perceptions of ethical workplace decisions. 


\section{Literature Review}

Research in intervention development engages in a robust preliminary investigation of the literature especially focusing on case studies of current practices (Maslowski, 1999). It is difficult to assess the weight of various studies on the impact ethic's training has on individuals because of the varied methods and instruments used to measure assessment. Most of the literature concerning assessment is quantitative in nature, but the similarities end there. Different forms of statistical analysis, the use or lack of a theoretical foundation, and various forms of instruments for measurement shift the focus of each study, consequently numerous interpretations of the findings abound.

Most of the literature concerning the changes in cognitive thinking (Arlow \& Ulrich, 1988; Stead \& Miller, 1988; Weber, 1990) or behavior and attitudes (Fritzsche \& Becker, 1983; Gautschi \& Jones, 1998; Glenn, 1992; Martin, 1981; Weber, 1992; Wynd \& Mager, 1989) of students in ethical decision making comes from the 1980s and 1990s. Current research focuses more on developing critical thinking skills which increase the chances individuals will make more ethical decisions (Carlson \& Burke, 1998; Klugman \& Stump, 2006; Meisel \& Fearon, 2006). A literature search was conducted utilizing the key words ethical decision making, intervention, constructionist theory, pre- and post-test surveys, and cognitive and affective perceptions in Google Scholar. I used the bibliographies from the articles and books resulting from Google Scholar as further reference sources. I begin this review by looking at pre and post-test survey literature followed by literature reflecting a brief history of constructionist theory and cognitive moral development, and then move to literature concerning ethical decision-making in the workplace.

\subsection{Pre and Post-test Literature Review}

This summative review is a longitudinal study based on a previous pilot study conducted by the author using a small data set of participants which are included in the data used for this study (Walker, 2011). Building upon Weber's (1990) and Glenn's (1992) summary review of pre/post surveys to assess the impact of teaching ethics to students, this study provides a review to date of pre/post survey studies and their evaluations. This study furthers informs the literature by assessing the impact of an ethics course, Ethical Dilemmas in the Workplace, delivered in an online format to students enrolled in one large Midwestern urban university.

The use of a scenario based survey instrument for data gathering "began in 1961 with Baumhart's study of manager's values and ethics (Baumhart, 1961), [though] much of the work [using scenario based instruments for data gathering] has been published since 1985" (Weber, 1990, p. 153; Weber \& Green, 1991). This study used an already established set of scenarios called vignettes developed by Fritzsche and Baker (1983). These scenarios included five categories of ethical problems in the workplace covering "coercion and control, conflict of interest, physical environment, paternalism, and personal integrity" (Fritzsche \& Becker, 1983, p. 292). Fritzsche and Baker (1983) explain these scenarios were largely taken from material used at the Summer Institute on Ethical Issues in the Management of Public and Private Institutions and were chosen because they included "background information required to understand the dilemma" (p. 292) and had been pretested by a group of individuals working in the area of ethics. Building upon previous sets of already developed scenarios may allow for "cross-study comparison" (Weber, 1990, p. 154) and serve the purpose of validating or questioning past and future studies.

Since this particular study explores union as well as non-union workplaces, new scenarios were necessarily developed by the principal investigator to cover union workplaces. Weber (1990) suggests that "researchers may want to consider using a combination of contexts in their scenarios depending upon the research focus" (p. 143). Realistic scenarios were developed following a prescription designed by (Fredrickson, 1986) which emphasizes that:

the benefit of a scenario comes from its ability to present respondents with a reasonably realistic, detailed situation [in which the] context, problem, described actions, and terminology can all be written in such a way that the scenario generates interest, and therefore 'involvement', by the respondents (p. 481).

Care was taken in the use of relevant hypothetical scenarios for students who may never have been exposed to a union or a non-union workplace "since the "students' ability to understand the case and comprehend the level of decision making may be lacking" (Weber, 1990, p. 143).

\subsection{Ethical Decision-making as it Pertains to Cognitive Moral Development}

The study of ethical decision-making as it pertains to cognitive moral development has been influenced by Piaget (1932/1965), Kohlberg (1976), and Rest et al, (1999). These theorists conceptualize ethical decision-making from a constructivist approach. Piaget married the concepts of cognitive development and 
moral development and explained why individuals valued certain things. Kohlberg further explained that individuals interpret situations and make meaning which translates into moral judgments. He disavowed the idea that meaning or moral judgments were derived from social stimuli (Carpendale, 2000). Kohlberg's contention was that ethical dilemmas were "ones of conflict of perspective or interest; justice principles are concepts for resolving these conflict ... a person's sense of justice is what is most distinctively and fundamentally moral" (L Kohlberg, 1976, p. 40). Rest further advanced the constructivist approach to resolving ethical dilemmas by suggesting cognitive moral development occurs within a range of stages instead of moving sequentially through stages as Kohlberg posited. He developed a four component model of personal ethical development: ethical sensitivity or awareness, the ability to recognize the presence of an ethical issue; ethical or moral judgment, the ability to decide on the right course of action; ethical motivation or intent, the personal disposition to do what is right; and ethical character or behavior, the self-discipline or courage to do what is right under pressure ( $\mathrm{O}^{\prime}$ Fallon, 2005; J. Rest, 1986). Rest suggests all four components interact and influence each other and that moral failure occurs when an individual experiences deficiency in any one of the components.

Lind (2010) suggests an individual's moral behavior is dependent upon that individual's moral principles. To conceptualize this relationship, Lind posits the concept of cognitive structure, which he calls the power of moral thinking, impacts the "degree to which moral maxims or principles are brought to bear in specific situations," (Lind, 2010, p. 30) which he calls content or observable behavior. Based on the Kantian concept of the power of judgment, these cognitive structures help determine which moral maxims or principles to apply in any given situation based on the individual's interpretation of his or her own value and belief system or socio-moral perspective. In other words, individuals make ethical decisions, based on what they believe they know. Lind (2010) acknowledges Kohlberg's development of a stage scheme which measures individual moral development and the existence of cognitive development theory which houses the concepts of structure and content. In order to change a cognitive moral structure, we create hypothetical dilemmas (scenarios) which change the context in which the individual makes decisions. This intervention "tests the boundary between the 'artificial world' created by an education curriculum and the 'real' seemingly unchanged world of work" (Oser, 2010, p. 157).

Kohlberg's levels of moral-cognition are determined by an individual's actions based on his or her socio-moral perspective (J. R. Rest, \& Narvaez, D, 1994). These stages reflect the cognitive and affective dimensions of an individual's moral development. Utilizing Lind's concepts of structure and content, I turn to the literature reflecting the conceptual framework of the cognitive and affective perceptions of ethical decision-making and explore workers' ethical decision-making situated within the context of the workplace. I define workers as wage earners so the literature reflects workers in both labor and management.

\subsection{Ethical Decision-making in the Workplace}

Much of the ethical-decision making literature focuses on the business or management side of the labor-management relationship within the workplace and is derived from normative ethics, the realm of moral philosophy which guides individual behavior, and more specifically descriptive or empirical ethics, a form of normative ethics, concerned with explaining and predicting individual behavior in the workplace. A comprehensive review from 1996-2003 summarizing this literature includes over 170 studies based on Rest's (1986) theoretical model. Rest's advanced the field of descriptive ethics by creating a model or moral decision-making and subsequent researchers have generally supported Rest's model. Though this review includes findings regarding ethical decision-making in relationship to each of Rest's components, of particular interest to this paper are the conclusions drawn from the philosophy/value orientation variable as it relates to each of Rest's components. The philosophy/value orientation suggests individuals make ethical decisions based on moral awareness, judgment, or intent.

According to O'Fallon (2005), one trend in empirical research receiving attention is "the philosophy/value orientation -in particular, idealism versus relativism" (p. 400) which suggests "idealistic individuals tended to be more ethical than relativistic individuals" (p. 400). The philosophy/value orientation variable reflects the subjects' connection between idealism and deontological perspectives which posit an action is determined to be moral based on a comparison to some absolute truth of fixed moral principle or relativism and teleological perspectives to ethical decision making. Of the forty-two studies relating to the philosophy/value orientation variable examined, idealism and deontology, the pursuit of noble principles and right actions, were positively related to ethical decision-making while relativism, teleology, and economic orientation, or criterions of judgment related to individuals, situations, or the environment, were negatively related to ethical decision-making. 
A comprehensive review of 110 articles covering 1994-1999 finds that deontology and teleology significantly influences the decision-making process (Loe, Ferrell, \& Mansfield, 2000). A comprehensive review covering 1975-1992 finds only one study concerning a philosophy/value orientation (Ford \& Richardson, 1994) which suggests a positive correlation between values and positive ethical behavior in professionals (Allen \& Davis, 1993).

Little research specifically devoted to the philosophy/values debate exists outside of the business or management literature, but there does exist research which explores the affective and cognitive literature in terms of ethical decision-making. The connection between philosophy and values and affects or emotions and cognition or rational thinking is very strong. Affective components, found in the models presented by Rest (1984) and Jones (1991), implicitly influence many decisions. Decision-making then becomes "introspective, and retrospective, sporadically rational, ultimately affective and altogether imaginatively unbounded" (Langley, Mintzberg, Pitcher, Posada, \& Saint-Macary, 1995, p. 277). This denotes a shift in the literature on decision-making from a rational cognitive perspective toward a more affective perspective. The acknowledgement that affect plays a role in decision-making is supported by many (Forgas, 2001, p. 6). The influences of affect on ethical decision-making reflect the tension between the way things are and the way things ought to be. Therefore, affect influences the awareness or moral sensitivity of the ethical decision-making process (Rest \& Narvaez, 1994). Affect also influences ethical reasoning or judgment. Deciding on the right course of action has significant consequences for the decision-maker and other stakeholders (Izard, 2000). Finally, affect links moral sensitivity and moral reasoning (Weiner, 1997). According to Weiner (1997), affect is primarily responsible for the motivation to act and is the catalyst needed to spur behavior.

Contributing to the philosophy/value orientation debate, this paper explores student responses to ethical situations in workplace environments before and after the intervention of an ethic's class. The intent of this measurement is to determine if students exposed to this intervention make more positive decisions concerning ethical dilemmas than they made prior to the intervention.

\section{Theory}

The theoretical rationale for this evaluation is constructivist theory, a theory about learning which explains how individuals "know" and "come to know" something. From a constructive perspective, knowledge is "temporary, nonobjective, developmental, internally constructed, and socially and culturally mediated" (Reeves, 2003). Constructivism means forming one's own opinions, values, and beliefs based on one's own knowledge and any new information which might mediate that knowledge. The classroom becomes a microcosm of society reflecting different and diverse viewpoints. Teachers assume the role of facilitator rather than lecturer. Learners take on more of an ownership role in learning and thus the social relationship between teacher and learner is one of reciprocity and mutual respect within a learning community.

\section{Methodology}

A total of 145 undergraduate and graduate students formally enrolled in the fall, 2009, spring and fall, 2010, and the spring and fall, 2011 ethics classes were asked to respond to one pre-semester survey and one post-semester survey which included the same nine scenario-based questions. One open-ended question asking participants to describe any changes in their belief/value system, perspectives on considering other's viewpoints in ethical decision making, and their application of new information to ethical dilemmas was added to the post-survey survey. Eighty-one respondents filled out the pre-survey while fifty-nine respondents filled out the post-survey. Fifty-two female students (64\%) and twenty-eight male students (35\%) responded to the pre-semester survey; thirty-nine female students (66\%) and twenty male students (33\%) responded to the post-semester survey. There were no prerequisites for the class, and students self-selected into the study. There were no penalties for students who did not participate. The average age of the students was 24 , and the average work experience of the students was 5-10 years. See Table 1. 
Table 1. Pre-test and Post-test Demographic Data for Ethical Decision-making Survey

\begin{tabular}{lll}
\hline Categories & Pre-survey responses & Post-survey responses \\
\hline $\begin{array}{l}\text { Enrollment total and requested } \\
\text { participation: } 145\end{array}$ & $81(55 \%)$ & $58(40 \%)$ \\
Undergraduate/Graduate & $59(93.8 \%) / 3(.05 \%)$ & $55(93 \%) / 4(6 \%)$ \\
& & \\
Gender: Male/Female & $28(35 \%) / 52(64 \%)$ & $20(33 \%) / 39(66 \%)$ \\
Are range & & \\
$16-20$ & $1(1 \%)$ & 0 \\
$21-25$ & $30(37 \%)$ & $19(32 \%)$ \\
$26-30$ & $36(44 \%)$ & $5(8 \%)$ \\
$30+$ & $44(54 \%)$ & $35(59 \%)$ \\
& & $2(3 \%)$ \\
Word experience in years & $8(10 \%)$ & $9(15 \%)$ \\
$0-1$ & $12(15 \%)$ & $16(27 \%)$ \\
$2-4$ & $21(26 \%)$ & $32(54)$ \\
$5-10$ & $39(48 \%)$ & \\
$11+$ & Responses total to 80. One participant \\
& didn't complete any responses. \\
\hline
\end{tabular}

Comparisons of the pre-survey and post-survey responses to the scenarios serve as the measure of changes in ethical decision-making. Pattern, theme, and content analysis are used in the assessment of whether or not student's cognitive or affective thinking changed after completion of the course. Using open coding, the data are searched to find predominant or descriptive phrases which suggest core patterns. From these patterns, broader themes are drawn which are then channeled into broad categories. This "classifying and coding [of] qualitative data formed the framework for organizing and describing what has been collected" (Patton, 2002, p. 455) during the data collection phase of this paper and provided a foundation for the interpretative phase where comparisons of pre- and post-survey responses were made. Differences in the number of pre- and post-survey responses are noted in each category for each scenario.

The scenarios, described later in this paper, focus on ethical dilemmas in various workplace settings. In each scenario, the student is given a predetermined identity or specific role, such as manager of or worker in the company, and asked what $\mathrm{s} / \mathrm{he}$ would do in each of these scenarios. The narrative responses provide data from which comparisons of changes in ethical decision-making is made.

\section{Findings}

The coding from both pre- and post-survey responses resulted in the same six major categories of student action for eight of the nine scenarios: acquiescence (meaning to comply or go along with the organization's wishes/demands), repudiation (meaning not to comply with the organization's wishes/demands), whistleblowing (reporting unethical conduct to a higher authority), discussion (exploring and discussing situations prior to taking action), exiting the firm (quitting the job), and unsure. Scenario four which deals with conflict of interest yielded a seventh category of neutral. Post-survey responses reflect a change in the number of student responses which fit into each category from pre-survey responses but not a change in category. The shift in the number of responses from one category to another suggests students changed their cognitive and affective thinking from one position to another as a result of new information from ethics instruction. This fits into constructivist theory which suggests students mediate their existing knowledge with new knowledge to form new "opinions, values, and beliefs" (Reeves, 2003). Not every student responded to every pre-survey and post-survey scenario. Following is a summary of the data collected from scenario-based student responses, tables reflecting the number of pre- and post-survey responses divided by category, shortened descriptions of the findings, and a brief explanation of the cognitive and/or affective changes noted between the pre- and post-survey responses.

Scenario one dealt with coercion and control: You are the CEO of Rollfast Bicycle Company which has been barred from entering the market in a large Asian country by collusive efforts of the local bicycle manufacturers. Rollfast could expect to net 5 million dollars per year from sales if it could penetrate the market. Last week a 
businessman from the country contacted you and stated he could smooth the way for the company to sell in his country for a price of $\$ 500,000$. Question: What would you do in this situation?

Categories and the number of times they appear are shown in Table 1. The themes from which the categories are derived follow the category in parenthesis.

Table 2. Coercion and Control: Pre/Post Test Response Categories

\begin{tabular}{lll}
\hline Categories & Pre-survey responses & Post-survey responses \\
\hline Repudiation (decline) & 26 & 33 \\
Acquiescence (participate if & 28 & 18 \\
legal/opportunity) & & 7 \\
Unsure & 7 & 7 \\
\hline
\end{tabular}

This scenario suggested a way for a firm to enter a previously barred market by paying bribe money to a businessman who offers to "smooth the way for the company to sell in his country for a price of $\$ 500,000$." Pre-survey responses grew from 26 to 33 Post-survey responses for repudiating or declining the invitation. Student responses included" it is illegal," "it is not ethical to take the man's offer," and "I would turn the offer down. Even if I paid him that leaves the door open for him to blackmail me (and my company) for more especially if the any other member of the board knew of the deal (Bernie Madoff comes to mind to me)." Such responses suggest students were aware of corporate fraud in the current business environment and may have declined to participate for fear of criminal punishment. Some student responses in the pre-survey reflected the businessman's suggestion as an opportunity while other students disclose the transaction as "the cost of doing business" or "if there is an opportunity to make a profit, I will try to see how I could do it." Other students in the pre-survey suggested the deal might not be legal.

In post-survey responses, declining the invitation for one student was a matter of conscience. S/he responded, "First thing you do is think about the consequences of getting caught.... I would tell the man no because my conscience would know that it is wrong no matter if I got caught or not." The mention of conscience implies an ethical choice has been made to do what is right. Other students viewed the businessman's suggestion as an opportunity saying, "Well this is going to [be] a good choice for me to make. I will rather try to see what is going to be good for my business and ... I will go for it." One student remained unsure in the post-survey.

The bulk of responses repudiated the businessman's offer both in pre- and post-survey responses. Several responses suggested a cognitive change in the acquiescence category for scenario one. Pre-test responses suggest 28 students would participate in the collusion if the transaction were a legal opportunity. Post-test responses reflect only 18 students would view entry into foreign competition as an opportunity if it were legal. This denotes a change in cognitive thinking toward viewing possible repercussions/backlash if the transaction turned out to be fraudulent. One student response moved into the unsure category also suggesting there should be more consideration of the issue. This shift toward taking more precautions in making this transaction suggests some students are taking a broader view of the ethical dilemma and carefully weighing their options.

Scenario two also dealt with coercion and control: You are the treasurer of your union and keep immaculate records on union income and expenditures. Because of some health problems, you have been unable to perform you duties as treasurer for three months, and another union brother has taken over the treasurer's duties. Upon your return you find some minor discrepancies in the books and investigate the unusual expenditures. You find that your union brother has secretly taken small amounts of money from the union fund, which, if not brought to anyone's attention, might go unnoticed. You are aware that your union brother has some financial difficulties and that his home is in the foreclosure process. Question: What would you do in this situation?

Table 3. Coercion and Control: Pre/Post Test Response Categories

\begin{tabular}{lll}
\hline Categories & $\begin{array}{l}\text { Pre-survey } \\
\text { responses }\end{array}$ & $\begin{array}{l}\text { Post-survey } \\
\text { responses }\end{array}$ \\
\hline $\begin{array}{l}\text { Whistle blow (whistle blow first and then provide } \\
\begin{array}{l}\text { Restitution or } \\
\text { provide restitution and then whistle blow) }\end{array}\end{array}$ & 50 & 47 \\
Discussion & 11 & 12 \\
\hline
\end{tabular}


The scenario, within a union setting, adds a layer of complexity to the union members' relationship with each other. There is a presumption that solidarity within the union means union brothers and sisters look out for each other while maintaining the integrity of the union as a whole. Student responses to this ethical dilemma reflect the conflict between acting in a fiscally responsible manner and taking care of a union brother.

Fifty pre-survey responses suggest students would whistleblow either prior to or following a demand for restitution of the financial discrepancies. Responses included:

I would approach my union brother first to give him the opportunity to make it right. If he chose not to, since the funds (sick or not) are my responsibility, I would report it. I understand financial difficulties, but taking from others in the same boat isn't the way to fix it.

Another student said:

First I would approach my union brother and try to persuade him to begin repaying the union in small amounts. I would try to explain to him that everybody has a financial downfall at some point, but if everyone acts dishonestly there would be no one to trust in times of need. If he refused I would feel forced to report him to the proper authorities.

Some students did not mention talking to their union brother first about making restitution and leaned toward turning him in to protect themselves from rebuke. Their comments included, "I would turn him in because if they found out I could get in trouble and lose my job which is important to me" and "I would have no choice but to report him. Why risk my job, my family, my finances and the union's reputation for a guy who chooses to steal? No telling what he would do next!" Another student said, "I would feel obligated to come forward with the information immediately. I have a mortgage and family to support also, and cannot afford to take the blame for theft." One student's action would depend on "how much money he took." If repayment could be arranged, no repercussions would follow.

Forty-seven Post-survey responses reflected a somewhat softer approach to the ethical dilemma which may reflect students' leaning toward helping their union brother first and then requiring disclosure of financial discrepancies second. Responses included first turning in the union brother and then seeking restitution as reflected in this comment, "I will report the matter just to make my name clean and if I am able to help with his financial situation I will love to help." Some students framed the issue in black and white. They said, "I would expose the union brother. Stealing is not only illegal, but it is unethical," "I would turn him in, no matter what he is stealing," and "I would report my findings. There are many people having financial difficulties but that doesn't give anyone the right to steal."

Other students would confront their union brother and try to seek restitution before turning him in. They used phrases like "give him a chance to return the money, "or "give him an opportunity to return the stolen funds." One student suggested the union brother should be given an opportunity to repay his "Loan" by "promot[ing] a fund raiser to help with some of the repayment."

Eleven students in the Pre-survey would discuss and explore solutions before exposing the fraud. Responses included, "Talk[ing] to the union brother and maybe try to arrange an ethical recovery so he didn't get in trouble. Maybe we could take donations or something" and "I would have to talk to the union president about this situation and get his advice on how to proceed." Twelve Post-survey responses suggested discussion as a viable alternative.

Fifty pre-survey and forty-seven post-survey responses suggested some form of whistleblowing or telling a higher authority about the ethical dilemma. This ethical dilemma primarily reflected a shift in cognitive thinking within the category of whistleblowing. The whistleblowing took two forms: whistleblowing and then helping a union brother make restitution or helping a union brother make restitution and then whistleblowing. The cognitive shift lies in those post-survey responses which suggest students would attempt some form of restitution and/or discussion prior to whistleblowing. This cognitive shift suggests the intervention of new information in choosing between two equally unattractive alternatives shifts some responses from black and white alternatives to more nuanced responses.

Scenario three deals with conflict of interest: You are a union official. One of your members is discovered to have a history of mental illness and is going to be dismissed by his employer on that basis. You feel this is unfair. The member has appealed to you in your union role to help him protect his job. However, the other union members at the workplace share their employer's prejudices and do not want to work with this man because of his mental illness. They hold an informal meeting where they vote strongly not to support their fellow worker and convey their opinion to the union. Question: What would you do in this situation? 
Table 4. Conflict of Interest Pre-survey and Post-survey Responses

\begin{tabular}{|c|c|c|}
\hline Categories & Pre-survey responses & Post-survey responses \\
\hline Repudiation (stand with co-workers) & 6 & 2 \\
\hline $\begin{array}{l}\text { Acquiescence (stand with mentally ill } \\
\text { or support conditionally) }\end{array}$ & 43 & 51 \\
\hline Discussion (research condition of mentally ill) & 12 & 6 \\
\hline
\end{tabular}

This scenario challenges students to make a difficult ethical decision: to stand by a mentally-ill union brother or side with a majority of co-workers who do not want to work with a mentally-ill person. Pre-survey responses reflected forty-three students would support or conditionally support the mentally ill employee. Their responses included phrases like "defend the individual," "stand for the worker's rights," and "still support the person." Six students said they would support their coworkers because of majority consensus, and six students responded they would conditionally support their mentally ill coworker "depend[ing] upon...how severe it [the mental illness] is," "if the illness did not hinder the member from properly executing his job, and did not endanger the well-being of other members," and "if I felt the worker was being penalized unfairly." Twelve replies favored researching discrimination against the mentally ill and reminding coworkers of privacy issues.

All but two post-survey replies suggested students moved in the direction of supporting or supporting conditionally the mentally ill worker while distancing themselves from other non-sympathetic coworkers. Fifty-one student responses supporting the mentally ill worker included phrases like "I'd stand up for the guy," "support the member," and "defend the man's job." Twelve responses suggested some type of conditional support for the mentally ill worker based on how the mental illness affected his work. One respondent wrote, "In my honest opinion, it would have to do with the type of mental illness," while a second respondent said, "I would help him to fight for his job in this situation if his illness did not affect his work." The shift toward favoring a helpful and supportive approach for the mentally ill coworker suggests students' ethical decision making broadened to include a human component and not simply a profit motive.

Scenario four deals with conflict of interest: You have recently accepted a job with a young vigorous microcomputer manufacturer. The microcomputer manufacturers are engaged in intense competition to become the first on the market with a software package which utilized the English language and thus is easily used by the average consumer. Your former employer is rumored to be the leader in this software development. When you were hired, you were led to believe your selection was based upon your management potential. The morning beginning the third week on the new job, you received the following memo from the president: "Please meet with me tomorrow at 8:15 am for the purpose of discussing the developments your former employer has made in microcomputer software. Question: What would you do in this situation?

Table 5. Conflict of Interest Pre-survey and Post-survey Responses

\begin{tabular}{lll}
\hline Categories & Pre-survey responses & Post-survey responses \\
\hline Repudiation (no comply) & 14 & 15 \\
Acquiescence (comply) & 11 & 13 \\
Walk tightrope & 22 & 21 \\
Exit firm & 4 & 4 \\
Discussion & 10 & 6 \\
\hline
\end{tabular}

This scenario places the student in an ethical dilemma between allegiance to a current employer or maintaining confidentially of a former employer. Pre-survey responses show that 14 students would not comply with their current employer's request for confidential information about their former employer's microcomputers. Responses include "I would decline the invitation, deeming it unethical," and "To pass on this information is comparable to theft." Eleven students felt compelled to comply unless bound by nondisclosure agreements. Twenty-two responses attempted to walk a tightrope between the information requests of the current employer and the past relationship with the former employer. This balancing act resulted in "play[ing] dumb," reveal[ing] information...if the circumstances I left under were negative," or "attend[ing] the meeting, and not saying a word." Four students felt strongly enough about the ethical dilemma to exit the firm. One student wrote, "I would quit and let my old employer know what was happening," while another student said, "I would rather lose 
a job than my professional reputation." One response involved discussing the conflict of interest with the president.

Post-survey responses reflected fifteen students would not comply with the request, an increase of only one non-compliance response, while 13 post-survey responses reflected compliance, up from two pre-survey responses. Twenty-one responses reflected walking a tightrope, down from 22 pre-survey responses. Four replies suggesting exiting the firm remained steady with pre-survey results. Six responses reflecting discussion, down from ten in pre-survey responses, marked the biggest change in this scenario suggesting students were more willing to discuss options concerning delivering confidential information to a current employer.

Scenario five dealt with physical environments: The firm for which you work, Master Millers, has developed a special milling process which yields a wheat flour which when used for bread provides a lighter more uniform texture than conventionally milled flour. Unfortunately, the process gives off more dust that the emission control equipment presently installed can handle and still maintain emissions within legal limits. Due to lack of availability, the company is unable to install new emission control equipment for at least two years; however, if it waited that long to introduce the new process, competitors would very likely beat it to the market. The general manager wants to use the new process during the third shift which runs from $10 \mathrm{pm}$ until $6 \mathrm{am}$. By using the process at that time, the new flour could be introduced and the excess pollution would not be detected due to its release in the dark. By the time demand becomes great enough to utilize a second shift; new emission equipment should be available. You are aware of this situation. Question: What would you do in this situation?

Table 6. Physical Environment Pre-survey and Post-survey Responses

\begin{tabular}{lll}
\hline Categories & Pre-survey responses & Post-survey responses \\
\hline Repudiation (protest) & 13 & 12 \\
Acquiescence (keep quiet) & 14 & 6 \\
Whistle blow & 17 & 19 \\
Discussion & 14 & 8 \\
Unsure & 1 & 15 \\
Exit firm & 1 & 2 \\
\hline
\end{tabular}

This scenario places workers in the position of remaining complacent concerning environmental hazards or exposing the firm for excess pollution, a sticky ethical dilemma. Four-teen pre-survey responses reflected keeping quiet by "keep[ing] my mouth shut," because "I could lose my job." Thirteen respondents would protest with one respondent saying "I would defiantly have to say something because I would not want to be breathing that in," and 17 respondents would whistle blow by alerting a higher authority such as OSHA. Four-teen individuals would explore or discuss the situation with the firm, and one individual was unsure of his/her response. S/he stated, "I honestly don't know if I would do anything." One respondent said they would exit the firm because "I would have to quit if there was no other solution to fix this temporary problem."

Post-survey responses suggested a more proactive move toward highlighting the firm's excessive polluting behavior. Post-survey responses reflected 12 individuals who would remain silent. One student stated, "If I had to choose between accepting this breach of ethics and being unemployed, I'd accept the breach of environmental ethics in this situation." Six individuals, down from 14 in the pre-survey, would passively protest but gave no sign of what their protest would consist. The drop in the number of those who would passively protest suggests ethical environmental standards are a concern and some action should be taken. Nineteen respondents said they would whistle blow by "going above the company to a higher power," "utilize[ing] the whistleblower policy because there are health risks involved," "confront[ing] the firm...go to higher power," and "tak[ing] my concerns public." Eight individuals, down from 14 in the pre-survey would explore and discuss by trying to find "some alternative ways this new flour could be introduced without the excess of pollution." The drop in the number of those who would rather discuss versus taking action again suggests an interest in correcting environmental wrongs. Five individuals were unsure of their responses, and two individuals said they would exit the firm.

Scenario six deals with physical environments: You are the business agent for the International Brotherhood of Printers, Local 20 which represents the employees of the firm, Print It Right. Print It Right, in order to comply with environmental regulations of the disposal of hazardous waste, must switch from using chemical-based ink in their printing process to water-based ink. Therefore, Print It Right must dispose of several hundred 55-gallon 
drums of chemical-based ink. The chemical-based ink must be neutralized before being sealed into the drums and before shipment and off-site storage occurs or the possibility exists that a non-neutralized drum of chemical-based ink could bulge, expand, and explode. You have been notified by one of your union members that she has been ordered by management to remove one 55-gallon drum of chemical-based ink which is bulging or be disciplined with a charge of insubordination. She tells you she asked her supervisor for protective equipment (goggles, protective suit), and he told her these items were not available. Question: What would you do in this situation?

Table 7. Physical Environment Pre-survey and Post-survey Responses

\begin{tabular}{lll}
\hline Categories & Pre-survey responses & Post-survey responses \\
\hline Repudiation (no comply) & 14 & 14 \\
Acquiescence (comply or comply with qualifications) & 8 & 3 \\
Whistle blow & 31 & 28 \\
Discussion & 8 & 5 \\
Unsure & 1 & 0 \\
\hline
\end{tabular}

This scenario revolves around the ethical dilemma of whether a representative of the union, a business agent, should give advice to a union member ordered to remove hazardous waste without protective clothing to comply with management's orders or to refuse to comply for safety reasons. Fourteen pre-survey responses suggested a refusal to comply by telling the worker and management "not to do the job without protective gear," while eight pre-survey responses advised the workers to comply "because it would probably be more trouble than it's worth [to not comply]." Two responses indicated compliance with qualifications by "investing in the protective equipment or else...deal directly with the employer over time." Thirty-one students indicated they would whistle blow including comments like "since the super has no regard for his employee's safety, I would take the matter up with his supervisor and the company's safety department" and "I would report Print It Right to the proper authorities." Eight responses reflected the need for discussion with management about providing protective equipment, and one of those responses suggested checking with management to see if "the union member may have been lying and didn't really ask the supervisor [for the protective equipment]. One respondent was unsure of what s/he would do.

Fourteen post-survey responses indicating a refusal to comply were very similar to pre-survey responses when considering noncompliance. Three post-survey responses indicated the worker should comply which was down from eight pre-survey responses. This drop in compliance may suggest an awareness of the dangerous ethical situation into which the worker would be placed. Two students responded they would comply with qualifications by "secure[ing]" or "find[ing]" the protective equipment themselves. Twenty-eight post-survey responses, down from 31 pre-survey responses, indicated they would whistle blow by "going to someone with more power," "go right over everyone's head," or "'confront' or 'talk' to the supervisor about safety precautions," and "tell him (the supervisor) that he will be reported to OSHA, EPA, and anyone else." A shift did occur from eight pre-survey responses indicating discussion and exploration to five responses indicating the appropriate solution would be to discuss the situation saying, "I would fight for her to receive protective gear." Moving from discussion involving a potentially hazardous situation to more definitive action suggests students may be more concerned with finding solutions to problems than simply talking about the problem. No student was unsure of what to do in the post-survey.

Scenario seven deals with paternalism: You are a senior editor of J\&P Publishing who has just received a manuscript from one of your most successful authors. The manuscript provides the most authoritative account yet published of the history of the development of Improvised Explosive Devises (IEDs). However, the final chapter contains a detailed description of how the IED is made. Jones has tried to convince the author to omit the last chapter stating that such information should not be made readily available to the mass market in paperback form. The author believes the chapter is critical to the success of the book and thus will not agree to its deletion. Question: What would you do in this situation? 
Table 8. Paternalism Pre-survey and Post-survey Responses

\begin{tabular}{lll}
\hline Categories & Pre-survey responses & Post-survey responses \\
\hline Repudiation (not publish) & 26 & 22 \\
Acquiescence (publish or publish with qualifications) & 27 & 21 \\
Whistle blow & 2 & 1 \\
Discussion & 6 & 9 \\
\hline
\end{tabular}

The ethical dilemma described in this scenario asks students to make a choice between publishing and disseminating potentially dangerous material or restricting an author's right of free speech. Twenty-six pre-survey responses leaned toward protecting free speech and were littered with phrases like "I would stick up for the author's rights," "freedom of speech prevails," and "we're talking about freedom of the press here." Twenty-seven pre-survey responses leaned toward not publishing the material saying "such information should not be made public...we are not liable for mass destruction or aided in terrorism," "in no way does this last chapter need to be in the book," and I would not publish a book that is a clear violation of national security and would put people in danger." These responses suggest very polarized dichotomies reflecting strong feelings about rights of free speech and the public's right to know. Two pre-survey responses reflected whistleblowing and one student said "I would take this to the courts to see maybe what a lawyer/judge says." Six students said they would discuss the matter with the publisher.

Post-survey responses seemed to move toward less polarizing stances. Twenty-one students, down from 27, responded they would publish the material; twenty-two students replied they would not publish the material, down from 26 in pre-survey responses, and two students decided to publish with qualifications stating, "I would not publish the book until the last chapter has been omitted," and "I would try and bargain with the writer as much as I can...if he did not agree to my terms then I would tell him to find another publisher." Only one student said s/he would whistle blow, while nine students said they were open for discussion. The change in attitudes from pre-survey responses to post-survey responses may suggest a more tolerant way of dealing with conflictual situations. There appeared to be a move toward more discussion and less overt action in publishing potential harmful information. The nature of the scenario which dealt with IEDs may also have triggered a more cautious response because of the current military conflict in which the United States is involved.

Scenario eight deals with paternalism: You are a union official who represents workers in a large firm that makes paper products. A new product line is to be manufactured. This restructuring means there will be jobs eliminated because the new equipment can produce more efficiently than can human labor. According to the contract, this job elimination can take place. One of the employees who will lose his job as a result of this restructuring is also your good friend who has a young son with a rare form of cancer, and he depends on the insurance from his job to cover the cost of cancer treatment. Without proper medical care, this young boy's suffering will increase. As a union official, you have the obligation to enforce the contract between your union and management. Question: What would you do in this situation?

Table 9. Paternalism Pre-survey and Post-survey Responses

\begin{tabular}{lll}
\hline Categories & $\begin{array}{l}\text { Pre-survey } \\
\text { responses }\end{array}$ & $\begin{array}{l}\text { Post-survey } \\
\text { responses }\end{array}$ \\
\hline $\begin{array}{l}\text { Repudiation (not enforce the contract) } \\
\text { Acquiescence (enforce contract or enforce contract with }\end{array}$ & 2 & 3 \\
qualifications) & 52 & 27 \\
Discussion (explore) & 4 & 21 \\
Unsure & 4 & 2 \\
\hline
\end{tabular}

Fifty-two pre-survey responses suggested enforcing the contract. One student said, "I would pray and then do my job." This implies an ethical decision is made based on the guidance of a higher power. Another said "I would jeopardize my job for him because [his] son's health is important." This response also suggests a decision made between two equally unattractive alternatives: losing one's job or sacrificing one's friend's job. Included in the 52 responses suggesting enforcement of the contract were those who implied they would enforce the contract with qualifications. Those qualifications included helping the worker find another job or insurance "like COBRA." Four responses involved exploring and discussing "some way to help the company and help the 
family at the same time." Four respondents were unsure what they would do. Their comments included comments like, "I honestly do not know" and "that's a tough one."

Post-survey responses reflected a marked shift in addressing this ethical dilemma. While twenty-seven post-survey respondents would still enforce the contract with or without qualifications, down from 52, only three respondents said they would not enforce the contract. Twenty-one responses suggested they would discuss and explore ways to "keep a job for my friend," and "do whatever I could at the bargaining table to preserve jobs and insurance benefits." This shift away from contract enforcement and toward exploration and discussion suggests respondents did not see alternatives as either black and white but as gray areas in which there might exist room for compromise. This also suggests a tendency to explore solutions from different perspectives which include a human component.

Scenario nine deals with personal integrity: Personal Integrity: You are working in product development for an auto parts contractor. Your firm received a large government bailout this summer to manufacture transaxles to be used in a new line of front wheel drive cars which a major auto manufacturer plans to introduce in the near future. The contract is very important to your firm which has recently fallen on hard times. Just prior to obtaining the bailout, half of the firm's employees, including you had been scheduled for an indefinite layoff. Final testing of the assemblies ended last Friday, and the first shipments are scheduled for three weeks from today. As you began examining the test reports, you discovered the transaxle tended to fail when loaded at more than $20 \%$ overrated capacity and subjected to strong torsion forces. Such a condition could occur with a heavily loaded car braking hard for a curve down a mountain road. The results would be disastrous. The manufacturer's specifications call for the transaxle to carry $130 \%$ of its rated capacity without failing. You showed the results to our supervisor and the company president who indicated they were both aware of the report. Given the low likelihood of occurrence and the fact there was not time to redesign the assembly, they decided to ignore the report. If they do not deliver the assemblies on time, they would lose future contracts and possibly have to return part of the bailout money. Questions: What would you do?

Table 10. Personal Integrity: Pre-survey and Post-survey Responses

\begin{tabular}{lll}
\hline Categories & $\begin{array}{l}\text { Pre-survey } \\
\text { responses }\end{array}$ & $\begin{array}{l}\text { Post-survey } \\
\text { responses }\end{array}$ \\
\hline $\begin{array}{l}\text { Repudiation (enforce contract or enforce contract with } \\
\text { qualifications) }\end{array}$ & 11 & 8 \\
Acquiescence (continue production) & 11 & 4 \\
Exit firm & 6 & 1 \\
Whistle blow & 26 & 29 \\
Discussion & 6 & 10 \\
Unsure & 2 & 0 \\
\hline
\end{tabular}

This scenario involves whistleblowing on a firm which produces a potentially hazardous product for the public. Eleven pre-survey respondents suggested they would continue production with one respondent replying "the future of the company and my job could be in trouble if they [the transaxles] were not delivered on time." Twenty-six respondents said they would whistle blow by "report[ing] the company," "imform[ing] the government," "consider OSHA," or "report to upper management." The trend in these responses was to report to a higher authority regardless of the variation in the organizations to which the information would be delivered. Six respondents would exit the firm and said "I would just try to find a job at a rival company and see if there was any way to destroy my prior company." Six responses suggested discussion in an attempt to make the company "do what's right in that situation." Two respondents would do nothing and one of them said, the firm "would have to suffer the loss."

Post-survey responses suggested a movement toward more whistleblowing, more discussion, and more uncertainty in choosing between unattractive choices. Post-survey responses suggested only four respondents would continue production. One comment qualified future production by saying, "I would work to redesign the assembly." Twenty-nine responses reflected whistleblowing, up from 26 in the pre-survey responses, and the rhetoric shifted from merely whistleblowing to a higher authority to including issues of safety and human life. Responses included, "Lives are more important than money," and "They have no right to put people's lives in danger." One response suggested exiting the firm, no responses were unsure, and ten responses reflected more exploration and discussion. The uptick in responses reflecting whistleblowing and discussion and fewer 
responses reflecting continued production or exiting the firm suggested students were more attuned to choosing responses in ethical situations which benefited human beings over contracts or profits.

One final opportunity for student feedback was given. Students were asked to: describe how this course may have changed/altered your value/belief system, your openness to other's perceptions/viewpoints about ethical dilemmas, or the way you make ethical decisions. Fifty-two responses reflecting students' perceptions about the course were received. No responses reflected the course as changing/altering established value/belief systems. Some responses reflected their value/belief system was strengthened because "This course helped me to understand how I gained this sense [of morals] and why," and "this course helped to reinforce what I already knew." All responses suggested the course positively benefited them by broadening perspectives about ethical situations and dealing with ethical situations in the workplace. Respondents said they were now more open to other's perceptions/viewpoints. Comments included "I can think more rationally about decisions and consider everyone's point of view better in my decision making;" I will look at all sides of the situation...before making a decision;" "It showed me that before I make a judgment I should look into the whole situation," and "I have learned to allow everyone their say in the decision process." Two respondents' observations reflect a changed way of making ethical decisions. They said, "I can choose to act ethically even if others will not act ethically....I can control me," and "I will use this model [the Justice model] as a guide to help me make the right choices."

\section{Conclusion}

This evaluation of changed student perspectives in making ethical decisions in the workplace as a result of taking an ethics class suggests the intervention of an ethics class does encourage students to be more open in accepting other's perspectives by taking into consideration other viewpoints and does strengthen already existing value and belief systems.

As evidenced by students' comments concerning how the course may have altered their thinking about ethical dilemmas, the findings suggest students, as learners, used new information to better understand their own perspectives/viewpoints concerning making ethical decisions, a central tenet of constructivist theory in which the learner comes to "know" from being exposed to new information. The findings from this summative evaluation reinforce the findings from an earlier pilot study conducted by the PI.

\section{Limitations to the Study}

This summative evaluation may yield different results participants. The interpretation of participants' responses or "meaning-making" (Patton, 2002, p. 478) may be limited by the primary investigator's knowledge, experience, and education. The responses given by participants represent the actions participants believed they would take after the culmination of an ethics class. Participant's actual responses may vary when faced with real situations in the workplace.

\section{References}

Abell, J. D. (1990). A note on the teaching of ethics in the MBA macroeconomics course. Journal of Business Ethics, 9(1), 21-29. http://dx.doi.org/10.1007/bf00382560

Allen, J., \& Davis, D. (1993). Assessing some determinant effects of ethical bonsulting Behavior: The case of personal and professional values. Journal of Business Ethics, 12(6), 449-458. http://dx.doi.org/10.1007/BF01666559

Anderson, J. (2008). Regulating corporations the American way: Why exhaustive rules and just deserts are the mainstay of U.S. corporatist goverence. Duke Law Journal, 57(1080), 1081-1112.

Arlow, P., \& Ulrich, T. A. (1988). A longitudinal survey of business school graduates' assessments of business ethics. Journal of Business Ethics, 7(4), 295-302. http://dx.doi.org/10.1007/BF00381835

Baumhart, R. C. (1961). How ethical are businessmen? Harvard Business Review, 39(4), 156-176.

Boyd, D. P. (1981). Improving ethical awareness through the business and society course. Business and Society, 20(1), 27-31.

Briggs, W. (1993). Computers and conscience: Personal ethics issues in the education of microcomputer users. In R. Gribben (Ed.), Ethics and Information Technology (pp. 18-35).

Carlson, P. J., \& Burke, F. (1998). Lessons learned from ethics in the classroom: Exploring student growth in flexibility, complexity and comprehension. Journal of Business Ethics, 17(11), 1179-1187. http://dx.doi.org/10.1023/A:1005740923813 
Carpendale, J. (2000). Kohlberg and Piaget on stages and moral reasoning. Developmental Review, 20(2), 181-205.

Cohen, E., \& Cornwell, L. (1989). A question of ethics: Developing information system ethics. Journal of Management Development, 2(2), 28-38. http://dx.doi.org/10.1007/BF00381809

Derrida, J. (1978). Writing and difference. Chicago: University of Chicago Press.

Drucker, P. (1981). Ethical chic. Forbes.

Ford, R. C., \& Richardson, W. D. (1994). Ethical decision making: A review of the empirical literature. Journal of Business Ethics, 13(3), 205-221. http://dx.doi.org/10.1007/bf02074820

Fredrickson, J. W. (1986). An exploratory approach to measuring perceptions of strategic decision process constructs. Strategic Management Journal, 7(5), 473-483.

Friedman, M. (1970). The social responsibility of business is to increase its profits New York Times.

Fritzsche, D. J., \& Becker, H. (1983). Ethical behavior of marketing managers. Journal of Business Ethics, 2(4), 291-299. http://dx.doi.org/10.1007/BF00383187

Gautschi, F. H., \& Jones, T. M. (1998). Enhancing the ability of business students to recognize ethical issues: An empirical assessment of the effectiveness of a course in business ethics. Journal of Business Ethics, 17(2), 205 - 216. http://dx.doi.org/10.1023/A:1005740505208

Gilligan, C. (1982, 1993). In a different voice: Psychological theory and women's development. Cambridge: Harvard University Press.

Glenn, J. R. (1992). Can a business and society course affect the ethical judgment of future managers? Journal of Business Ethics, 11(3), 217-223. http://dx.doi.org/10.1007/BF00871969

Goodpaster, K. E. (1983). The Concept of Corporate Responsibility. Journal of Business Ethics, 2, 1-22. http://dx.doi.org/10.1007/BF00382708

Goree, K. (2007). Ethics in the workplace (2nd ed.): Cengage Learning.

Hoffman, M. S., \& Moore, J. M. (1982). Results of a business ethics curriculum survey conducted by the Centre of Business Ethics. Journal of Business Ethics, 7(2), 81-83. http://dx.doi.org/10.1007/BF00412075

John W. Budd, \& James G. Scoville. (2005). The ethics of human resources and industrial relations (1st ed.). Champaign: Labor and Employment Relations Association.

Kant, I. (1781, 1963). Critique of pure reason. London: Macmillan.

Kavthatzopoulos, I. (1991). Kolhberg and Paiget: Differences and similarities. Journal of Moral Education, 20(1), 47-54.

Klugman, C., \& Stump, B. (2006). The effect of ethics training upon individual choice. Journal of Further \& Higher Education, 30(2), 181-192.

Kohlberg, L. (1976). Moral stages and moralization: The cognitive developmental approach. New York: Reinholt and Wilson.

Kohlberg, L. (1981). The philosophy of moral development: Moral stages and the idea of justice (1st ed.). San Francisco, CA: Harper and Row.

Lind, G. (2010). The theory of moral-cognitive development : A socio-psychological assessment. In G. H. Lind, H.A. \& Wakenhut, R. (Ed.), Moral judgments and social education (pp. 21-54). New Brunswick: Transaction.

Locke, J. (Ed.). (1690). Two treatises of government. Cambridge Cambridge University Press.

Loe, T. W., Ferrell, L., \& Mansfield, P. (2000). A review of empirical studies assessing ethical decision making in business. Journal of Business Ethics, 25(3), 185-204. http://dx.doi.org/10.1023/a:1006083612239

Martin, T. R. (1981). Do courses in ethics improve the ethical judgment of students? Business Society, 20(2), $17-26$.

Maslowski, R. (1999). The potential of formative evaluation in program design models. In J. van den Akker, Branch, R.M., Gustafson, K., Nieveen, N., Plomp, T. (Ed.), Design approaches and tools in education and training (pp. 296). London: Klewer Academic Publishers. 
McDonald, G. M., \& Donleavy, G. D. (1995). Objections to the teaching of business ethics. Journal of Business Ethics, 14(10), 839-853. http://dx.doi.org/10.1007/BF00872350

Meisel, S. I., \& Fearon, D. S. (2006). "Choose the future wisely": Supporting better ethics through critical thinking. Journal of Management Education, 30(1), 149-176.

Mill, J. S. (1863, 2003). Utilitarianism. In G. Sher (Ed.), (2nd ed.). Indianapolis: Hackett Publishing.

O'Fallon, M. J. (2005). A review of the empirical ethical decision-making literature: 1996-2003. Journal of Business Ethics, 59, 375-413. http://dx.doi.org/10.1007/s10551-005-2929-7

Fritz Oser, \& Andre Schlafli. (2010). The thin line phenomenon: Helping bank trainees form a social and moral identity in their work place. In G. H. Lind, H. A., \& Wakenhut, R. (Ed.), Moral judgments and social education (pp. 155-172). New Brunswick: Transaction.

Patton, M. Q. (2002). Qualitative evaluation methods (3rd ed.). Thousand Oaks: Sage.

Provis, C. (2006). Industrial relations, ethics, and conscience. Business Ethics: A European Review, 15(1), 64-75.

Reeves, T. (2003). Interactive learning systems evaluation. Englewood Cliffs, NJ: Educational Technology Publications.

Rest, J. (1986). Moral development: Advances in research and theory. New York: Praeger.

Rest, J. R., \& Narvaez, D. (1994). Moral development in the professions: phychology and applied ethics. Hillsdale, New Jersey: L. Erlbaum Associates.

Stead, B. A., \& Miller, J. J. (1988). Can social awareness be increased through business school curricula? Journal of Business Ethics, 7(7), 553-560. http://dx.doi.org/10.1007/BF00382603

Walker, M. (2011). Syllabus: ethical dilemmas in the workplace. Syllabus. Indiana University Purdue University at Indianapolis. Indianapolis.

Weber, J. (1990). Measuring the impact of teaching ethics to future managers: A review, assessment, and recommendations. Journal of Business Ethics, 9(3), 183-190. http://dx.doi.org/10.1007/BF00382643

Weber, J. (1992). Scenarios in business ethics research: Review, critical assessment, and recommendations. Business Ethics Quarterly, 2(2), 137-160.

Weber, J., \& Green, S. (1991). Principled moral reasoning: Is it a viable approach to promote ethical integrity? Journal of Business Ethics, 10(5), 325-333. http://dx.doi.org/10.1007/BF00383233

Wynd, W. R., \& Mager, J. (1989). The Business and society course: Does it change student attitudes? Journal of Business Ethics, 8(6), 487-491. http://dx.doi.org/10.1007/BF00381815 